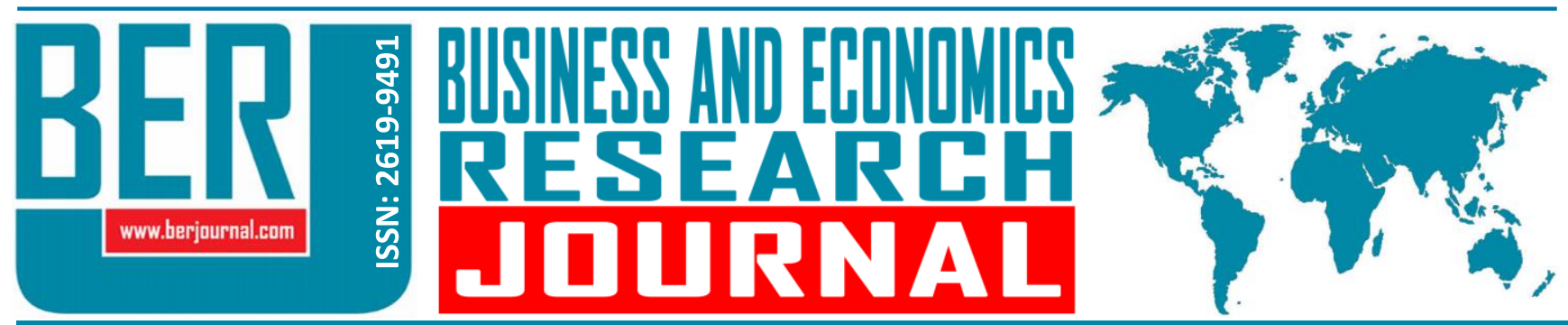

Business and Economics Research Journal Vol. 10, No. 1, 2019, pp. 77-94 doi: 10.20409/berj.2019.156

\title{
World Bank and Keynesian Economics
}

\section{Betul Sari Aksakal ${ }^{\mathrm{a}}$}

Abstract: The World Bank is an international development and financial institution, which was founded with the name of International Reconstruction and Development Bank and based within the United Nations, offers customized resources, development prescriptions, consultancies and loans to countries in various parts of the world. The largest part of the World Bank group is the World Bank which is the largest organization working on private sector initiatives and projects in developing countries; providing technical assistance and development proposals to businesses and governments. The adopted development approaches of this organization and its policy prescriptions to countries have evolved parallel to the periodic charecteristics of capitalism and the change in the economic theory corresponding to these periods since its foundation. It is possible to state that, roughly in the first 30 years, the Keynesian economic policies has affected development discourse and policies of the Bank. However, in the mid-1970s the Keynesian impulse went into reverse and replaced by neoliberalism under the effects of Vietnam War and the OPEC oil price shocks. After that, neoliberalism was on the stage until the 2008 financial crisis started in America and brought the whole world under its impact. This crisis has led the bank to change rhetoric and adopt Keynesian development policies. The main objective of this study sheds light on what Keynesian economics is, its main aims Keynesian development period of the World Bank and its reflections on Bank's development policies.
Keywords: World Bank, Keynesianism, Economic Development, Development Policies, Import Substitution Industrialisation

JEL: O19, F63

\section{Introduction}

Although the World Bank emerged during the Bretton Woods Conference in 1944, the roots of Keynesianism extend till to the crisis of $1873-1896$ as main solutions of some economic problems of the world.

The biggest crisis of industrial capitalism faced between 1873 and 1896 paved the way to the First World War. After that Great Depression, there was rapid decolonization period causing rapid rise of socialist and fascist regimes in Europe and the global system. All those events brought into mind some questions about the basic principles of classical liberalism and also the stability of the global capitalist system.

The Great Depression revealed the idea that there was a need to change economic system and policies instead of classical liberalism. John Maynard Keynes gave the response of that need in 1936 with his famous book "The General Theory of Employment, Interest and Money" which explains main reasons and also offers solutions for Great Depression. Keynes has brought some criticisms to the laissez-faire discourse of the classical liberalism and found it inadequate to serve as an explanation about the economic shocks and 
fiascos, because economic models of classical liberalism do not consider of occurrence extraordinary situations of economies (Balaam and Dilman, 2015: 70).

As a matter of fact, Keynesian economic policies, begining with the first application before General Theory through the New Deal Administration in the U.S., have moved to the international dimension after the Second World War. Bretton Woods Conference followed the War and the principles of the international economic system were identified during the Conference. Economic system was not organized as pure liberal form, but trade on money and capital market (markets) regime based on state hand in the system. This period has been called embeded liberalism by Ruggie (1982: 392-393). Embeded liberalism was proposing the state coordinated development process through the Bretton Woods regime and Keynesian economic policies. It included a number of objectives widely based on the revitalization of Western capitalism devastated due to the World Wars and Great Depression. In that context, the first mission was to revive free trade damaged by the World Wars and Great Depression. The second one was to give national governments freedom to create wide welfare programmes and to interfere in economies in order to sustain full employment. Following embeded liberalism period Hogan (1989: 13) made a statement on economic depression and the "New Deal" activism which has led to a redefinition of economic management and policies of the Keynesian strategy.

Furthermore, Keynesian economic theory has exerted a strong influence on development economics. By being contradicted with orthodox economics, Keynes had created the way to find new solution options to economic problems. Although he gave broad role to the public sector, he had also prepared a case for discretional national economic management. Therefore, public policy formation became much more active force in national economies (Meier and Seers, 1984: 14). The spirit of policies and discourses of the World Bank were characterized by the early views of Keynesian based development theories. That case, originated from the aim of the Bank at postwar reconstruction in Western Europe through the assisstance of foreign aid and some economic planning and cooperation, created optimism for the task of economic development in Latin America, Asia and Africa. Especially the role of planning reflected itself through the strategies of industrialization, import substitution, and the mobilization of resources in the interest of national development in 1950s. World Bank's major development themes such as attention on the capital accumulation, industrialization, and planning can be traced to Keynesian back ground.

Key factors on adoption, consolidation and decline of Keynesianism in the policies of the World Bank through the development economics will be assessed in this paper.

\section{Key Factors on Adoption of Keynesianism in The World Bank's Development Policies}

In its early years, the Bank's first fundamental mission was to help rebuilding Europe and the second was to promote economic growth of the countries in South, many of which were still under colonial rule (Toussaint, 2008: 17). In that point, it could be said that development was the second degree piority for the Bank. During the recovery period of Europe after the Second World War, the Bank defined its main route through the Keynesian economic policies.

On the other hand, there were some other dynamics directly affecting the international economic system, development strategies and the World Bank's development policies.

Soviet Russia finished the Second World War as one of the most powerful country in terms of industrial capacity and the second military power following the U.S. According to Hobsbawm (2015: 302), the period of history after the Second World War until the collapse of the Soviet Russia fused into a single model. As he stated: Cold War."

"After the Second World War, the two superpowers have confrontation in a continuous fight called

In that context, the World Bank began its operations in 1946 and lent mainly to industrialized countries of Europe during its the first year operations. It granted loans total just over $\$ 500$ million to countries in the Western Europe (\$250 million to France, $\$ 207$ million to the Netherlands, $\$ 40$ million to 
Denmark and \$12 million to Luxembourg) while only one loan was made to a developing country (\$16 million to Chile) in the period of between 1946 and 1948 (Toussaint, 2008: 19).

The World Bank's lending policy to Europe was radically destabilized and curtailed by the introduction of the Marshall Plan in 1948 (Toussaint, 2008: 19). Therefore, the Bank began to lose its mission to rebuild the European economies because of Marshall Plan. Addition, the Bank has changed its domain after that point and the most interested domains were the regions where were the most important areas for the U.S.'s jeostrategic objectives.

The United States devoted more than $\$ 13$ billion and $\$ 11$ billion to the Bank which was freely given, between 1948 and 1951 to restore the economy of 17 European countries in the context of the Organization for European Economic Cooperation (OEEC, today OECD) (Table 1) (Toussaint, 2008: 38).

Table 1. Expenses Involved in Marshall Plan Economic Assistance in the Period between 3 April 1948 and 30 June 1952

\begin{tabular}{|c|c|c|c|}
\hline Countries & Total & Grants & Loans \\
\hline & \multicolumn{3}{|c|}{ The U.S. Dollar } \\
\hline Austria & 677.8 & 677.8 & - \\
\hline Belgium-Luxembourg & 559.3 & 491.3 & $68.0^{\mathrm{a}}$ \\
\hline Denmark & 273.0 & 239.7 & 33.3 \\
\hline France & $2,713.6$ & $2,488.0$ & 225.6 \\
\hline Germany (FR) & $1,390.6$ & $1,173.7$ & 216.9 \\
\hline Greece & 706.7 & 706.7 & - \\
\hline Iceland & 29.3 & 24.0 & 5.3 \\
\hline Ireland & 147.5 & 19.3 & 128.2 \\
\hline Italy (including Trieste) & $1,508.8$ & $1,413.2$ & 95.6 \\
\hline Norway & 255.3 & 216.1 & 39.2 \\
\hline Sweden & 107.3 & 86.9 & 20.4 \\
\hline Portugal & 51.2 & 15.1 & 39.2 \\
\hline Netherlands (Indonesia) ${ }^{b}$ & $1,083.5$ & 916.8 & 166.7 \\
\hline Turkey & 225.1 & 140.1 & 85.0 \\
\hline United Kingdom & $3,189.8$ & $2,805.0$ & 348.8 \\
\hline Regions $^{c}$ & 407.0 & 407.0 & - \\
\hline TOTAL & $\$ 13,335.8$ & $\$ 11,820.7$ & $\$ 1,505.1$ \\
\hline \multicolumn{4}{|c|}{$\begin{array}{l}\text { Source: Toussaint, } 2008: 38 \text {. } \\
\text { aThe loan included } \$ 65 \text { million for Belgium and } \$ 3 \text { million for Luxembourg. } \\
\text { bMarshall Plan support to the Dutch East Indies (Indonesia) extended to the Netherlands } \\
\text { after the former became independent on } 30 \text { December } 1949 \text {. } \\
\text { Included the U.S. contribution to the European Payments Union (EPU), European social fund } \\
\text { of } \$ 361.4 \text { million. }\end{array}$} \\
\hline
\end{tabular}

The main goals of the United States via Marshall Plan were rebuilding of the war-devastated regions, modernization of industry and making European countries prosperous again. These goals can be defined as the economic aims of the plan. But on the other hand, Marshall Plan had political purposes beside economic goals. Against the back ground of the Cold War, and powerful socialist and communist parties in Western European countries, it also sought to prevent the continent from falling into the Soviet camp (Eichengreen, 2010: 3).

The recipients of Marshall Plan showed a strong recovery with the implementation of the Plan while they were on the brink of economic collapse. Consequently, industrial production in the recipient European countries leapt from just 87 per cent of pre-World War II levels in 1947 to fully 135 per cent in 1951, a 48 per cent jump in just four years. Moreover the resumption of growth was sustained and Europe embarked on a golden age of economic growth that spanned a period of decades (Eichengreen, 2010: 1). 


\section{Strengthening of Keynesianism: The Rise of Development Economics and Growth-Based Development Policies}

The World Bank defined its development discourse and mission on the growth basis of the development economics. That meant main doctrines and theories of the development economics oriented the actions and policies of the Bank. Moreover, the radical changes in the Bank's development discourse observed through the reconstruction programs which were results of the dominant development and economic theories of the 1950 s and afterwards.

It would be useful to provide some information about the rise of development ecomomics. After the Second World War, large capital surplus was formed in developed countries. Then, the surplus needed to be reassessed. During that period, it was necessary to expand the demand of imports and new investment areas for developed countries in order to prevent the depreciation of capital surplus. In this context, the first that came into mind was the less developed countries depended on imports. In addition, the economies of many of them were largely characterized with investment gaps.

Groups of countries taken into undeveloped category in the 1950s were often former colonial countries. Direct colonialism formally disappeared during this period (Başkaya, 2005: 29). Nevertheless, the concept of development has taken the place of colonialism. While the concept of development was only dealing with the development problems of the developed Western countries previously, it started to address undeveloped countries and the phonemenon of underdevelopment after 1950s (Kaynak, 2009: 30). Production of information for this area has revealed a separate discipline: Development economics. In this area, a wide development literature has arisen about the development of less developed countries.

Development economics requires an integrated international capital mobility and capital accumulation. The functions performed by the state in the accumulation process could be realized at the national level. In order to realize that in the international level, the realization of institutionalization was necessary. The World Bank was a piece of that process. Therefore, its development discourse can be defined with economic growth through which capital accumulation can be provided.

The emergence of development economics and modernization theory ${ }^{1}$ has affected the discourse of the Bank, too. Modernism puts people at its center and goes along with the Renaissance, Reform and enlightenment processes. The word of modern means scientific, industrial and powerful; on the other humane, participatory and democratic. The West (US and Western Europe) represents modern culture. Modernist discourse, inspired by 19th century liberal philosophy, directed to the development of third world countries following the development processes and strategies of the Western countries.

As a matter of fact, modernization theory, in terms of domestic politics of third world countries, has identified the mechanisms to ensure the continuation of the US hegemony and offered advices to the policy makers in these countries. The establishment of the social order proposed by political developments improving the understanding of the US intervention has led to the emergence of roles such as state building, nation building, making institutions, making the bureaucracy (Kesselman, 1973: 139-145).

Moreover, modernization theory supported by many disciplines such as economics, politics, sociology and antropology has especially affected the development policies and suggestions of the World Bank. The whole of Asia, the Middle East, Africa, and Latin America were turned with passion to the goal of modernization: to get themselves into take-off or to move to the stage beyond (Meier \& Seers, 1984: 238). Therefore, the Bank encouraged less developed and developing countries to take developed Western countries and the advocations of the Bank development via industrialization statements as examples for their own development process.

Beside those cases, the depression of the interwar period evoked the Keynesian economic theories of short-period business cycles and the possible threat of secular stagnation in mature capitalist countries. A return to the growth and development themes did not emerge until the post-Second World War and the late 1940 s and 1950s in many respects in the pioneering period of the new development economics focusing on the development problems of Asian, African and Latin American countries (Meier \& Seers, 1984: 3). Many economists and their economic theories advocates that the development of those countries depended on 
the pursuit of the true development policies and provision of the industrialization. Import Substitution Industrialization (ISI) has appeared in a such environment. ISI is a trade and economic policy which broadly advices replacing foreign imports with domestic production. With another saying it is an economic theory commonly used by developing countries or emerging market nations looking for to reduce dependence to developed countries and enhance self-sufficiency. This case reflected itself through quotes from especially the Latin America's most famous economists. The change in behavior toward industrialization was considered as a cure of the area's ills. For instance, as Raul Prebisch (1950: 6) stated in his well-known manifesto of 1949:

"Formerly, before the great depression, development in Latin-American countries was stimulated from abroad by the constant increase of exports. There is no reason to suppose, at least at present, that this will again occur to the same extent, except under very exceptional circumstances. These countries no longer have an alternative between vigorous growth along those lines and internal expansion through industrialization. Industrialization has become the most important means of expansion."

ISI strategies gained large importance for World Bank's development policies with the foundation of the United Nations Economic Commission for Latin America and the Carribean (UNECLAC or NEPAL). The main goal of the ISI theory is to protect, strengthen and expand local industries by using several methods containing tariffs, import quotas, and subsidized government loans. With this respect, it is possible to state that the term of development was preoccupied with industrializing; which largely tended to mean import substitution. Thus, the World Bank's trade and industrialization program in the 1950s and 1960s was to chase both import-substitution and export-promotion industrialization through a liberalized price rationing of inputs, protected by tariffs and in some ways organized by national economic planning (Kapur et al., 1997: 451). However, these kinds of programs and policies were gradually abandoned by the World Bank.

In all those contexts, especially during the 1950's and 1960s, the Bank's main development discourse can be defined as growth does it all, growth via industrialization, growth with import substitution policies and export promotion (Gilbert \& Vines, 2006: 88). The central idea about that came from the economic theories and ideas of Rosenstein Rodan who was the assistant director of the Economics Department of the World Bank between the years 1946 and 1952. His paper Economic Backwardness in Historical Perpesctive provided incentive to the Bank for big push ways of thinking about development as well (Rosenstein-Rodan, 1943).

Towards the goal of providing industrialization to countries, the World Bank gave the big importance to productive capital in direct investments. Moreover, in that way, developing countries were able to enhance and grow their industries and export raw materials, oil, tropical agricultural products to developed and highly industrialized countries. On the other hand, developed countries would have reached important market domains with the progression of developing countries (Zabçı, 2009: 34).

Addition, in those years, the policies, institutional structure and stability of the Bank were determined by regarding the satisfaction and priority of five countries, the United States, Japan, Germany, England and France, having the most voting rights at the Bank (Table 2 and 3) (Zabçı, 2009: 34).

Table 2. Geographical Distribution of Expenditures Rates of the Funds Loaned by The World Bank between 1946 and 1955

\begin{tabular}{llllll}
\hline & \multicolumn{5}{c}{ Years } \\
Regions & $1946-1951$ & 1952 & 1953 & 1954 & 1955 \\
\hline United States & 73.1 & 65.3 & 63.5 & 58.7 & 47.1 \\
Europe & 11.3 & 25.3 & 30.1 & 38.1 & 48.8 \\
Canada & 6.6 & 8.8 & 4.3 & 2.4 & 2.9 \\
Sub-total industrialized countries & 91.0 & 99.4 & 97.9 & 99.2 & 98.8 \\
Latin America & 8.3 & 0.5 & 1.1 & 0.4 & 0.1 \\
Middle East & 0.4 & 0.0 & 0.0 & -0.1 & 0.0 \\
Africa & 0.3 & 0.2 & 0.8 & 0.3 & 1.0 \\
Asia & 0.0 & 0.0 & 0.2 & 0.2 & 0.1 \\
\hline Source:
\end{tabular}

Source: World Bank Annual Reports, 1946 to 1955. 
Table 3. Distribution of Expenditure Rates of the Funds Loaned by The World Bank over Countries between 1946 and 1962

\begin{tabular}{|c|c|c|c|c|c|c|c|c|}
\hline \multirow[b]{2}{*}{ Countries } & \multicolumn{8}{|c|}{ Years } \\
\hline & $\begin{array}{l}\text { Until } \\
1955\end{array}$ & 1956 & 1957 & 1958 & 1959 & 1960 & 1961 & 1962 \\
\hline & \multicolumn{8}{|c|}{ Expenditure rate $\%$} \\
\hline Germany & 4.1 & 14.1 & 18.6 & 17.2 & 16.3 & 16.9 & 13.5 & 10.9 \\
\hline Belgium & 3.7 & 2.9 & 2.8 & 2.9 & 3.3 & 2.1 & 2.5 & 1.6 \\
\hline Canada & 5.6 & 7.0 & 6.0 & 1.1 & 2.0 & 2.3 & 1.5 & 1.1 \\
\hline The U.S. & 63.4 & 50.5 & 44.3 & 38.8 & 29.7 & 29.8 & 29.6 & 33.2 \\
\hline France & 2.7 & 3.3 & 3.5 & 1.2 & 5.2 & 6.7 & 12.0 & 12.3 \\
\hline Italy & 0.9 & 1.7 & 3.0 & 5.8 & 6.3 & 7.7 & 6.6 & 8.3 \\
\hline Japan & 0.0 & 0.2 & 2.2 & 8.3 & 6.2 & 3.9 & 6.1 & 5.0 \\
\hline Netherlands & 0.0 & 0.0 & 0.0 & 0.0 & 0.0 & 0.0 & 0.0 & 2.5 \\
\hline Sweden & 0.7 & 1.5 & 2.7 & 0.9 & 2.1 & 2.3 & 3.1 & 2.6 \\
\hline Switzerland & 2.1 & 2.3 & 1.9 & 1.3 & 2.7 & 4.3 & 4.5 & 3.6 \\
\hline The U.K. & 11.1 & 13.2 & 10.9 & 18.8 & 20.5 & 16.5 & 13.7 & 13.7 \\
\hline $\begin{array}{l}\text { Sub-Total } \\
\text { industrialized } \\
\text { countries }\end{array}$ & 94.2 & 96.7 & 95.9 & 96.3 & 94.4 & 92.5 & 93.1 & 94.7 \\
\hline Other countries & 5.8 & 3.3 & 4.1 & 3.7 & 5.6 & 7.5 & 6.9 & 5.3 \\
\hline Total & 100.0 & 100.0 & 100.0 & 100.0 & 100.0 & 100.0 & 100.0 & 100.0 \\
\hline
\end{tabular}

Source: World Bank, Annual Reports, 1946 to 1962.

It is possible to state that the Bank's policies and strategies were highly influenced by the HarrodDomar model in that period. Keynes's proposals and theories for less-developed and developing countries based largely on the state-intervention and central planning transposed through Harrod Domar model. Model was largely used in development economics in order to find an economy's growth rate in respect to the level of saving and productivity of capital. It was also adopted by the Bank as a way to define the amount of aid required to bring up poor countries to a more prosperous growth path. Especially after the 1950s, Harrod Domar model was largely used to find out the relationship between the aid and investment, inequality, consumption and investment.

Another point is worth to mention, according to Harrod-Domar Model, economic growth depends on the direct relationship between the capital and savings coming from both internal and external. In that context, the Bank often emphasized the need to resort the external funding to get rid of insufficient savings. With another saying, shortage of savings was seen as a fundamental factor for blocking of development; so influx of external funding was always necessary. Paul Rosenstein Rodan (1961: 107), the assistant director of the Bank, found the following formula to resort to foreign capital in order to solve the insufficient saving problem:

"Foreign capital will be a pure addition to domestic capital formation, i.e. it will all be invested; the investment will be productive or 'businesslike' and results in increased production. The main function of foreign capital inflow is to increase the rate of domestic capital formation up to a level which could then be maintained without any further aid."

It is possible to emphasize that the World Bank's development discourse was the economic growthbased development discourse especially through the 1950's. Furthermore, the Bank adopted both interventionist Keynesian economic theories and laissez-faire economics; with another words embeded liberal policies. All of them implied and reflected the both political and economic objectives of the Bank. The Bank's main policies and development discourse roughly stated in 1950's by Gwin (1997: 213) as follow:

“The late 1950's and early 1960's seem to have been motivated by three concerns: building a strong organization to promote a 'free and open world economy'; leveraging funds from the 
private market and other countries to ease the burden on the U.S.; and supporting countries deemed important to the U.S. interests."

But towards the 1960s, the influence of those theories started to lose its impact on the World Bank's policies. Keynesianism started to decline because growth rates were too low in especially developing and undeveloped countries of Asia, Latin America and Africa in 1960s. The failure of ISI came forward and its prediction about the economic and structural transformation did not take place in these countries. Nevertheless, they became more dependent on the international division of labour. On the other hand, the failure of the European centered economic theories based on modernization theory also arised. Those theories suggested the linear, uneven and ahistorical development process to the world; however, their nullity was understood through the realizing of the Third World and their development problems especially.

\section{Keynesianism Begins to Fall from Favour}

Roughly through the 1950's, the World Bank gave its direct attention to the infrastructure, agricultural and industrial investments. Actually, the Bank defined its policies on the axis of the development of the Western Europe through Marshall Plan. At the same time, the Bank's main focus from the beginning of the Cold War through the late 1950's was the prevention of spreading of communism via strategic plans and simultaneously development of the world's important countries for establishing strong international economic order under the hegemony of the the U.S. In order to realize that it largely used and proposed countries Keynesian economic policies and development theories as previously mentioned. The yields of the World Bank's policies, lending and investments dramatically shifted the Western Europe and Japan; but actually the Bank gave little attention to the other parts of the developing world. As late as 1960s, it was allocating only about two percent of its economic aid to Latin America and less to Africa (Rabe, 1988: 135136).

The main objective of foreign aids of the Bank through 1950's was the increasing the aggregated growth rate. Because, there was a belief that the growth would cause a trickle -down effect and thus poor countries would also benefit from that after a certain time. Mainly for this reason the development problems of Asian, African and Latin American countries with other definition Third World neglected by the Bank.

While the Bank's development discourse was understanding to raise GDP via the industrialization, Keynesian economic theories and policies through 1950's, now that discourse has been expanded to the fact which includes development problems and solutions of the Third World countries including their problems of income distribution and poverty, inequality between developed and the Third World Countries. Its strategies to achieve that development discourse were also shifted. The Bank, anymore, gave much more importance to capital accumulation, foreign exchange earnings, construction of large infrastructure projects like dams and power plants especially for small farmers, but renewable resources and the provision of social services in urban areas.

In fact through the 1950's, the Bank largely insulated itself from the development and poverty problems of the Third World. But with the establishment of International Development Association (IDA), the Bank started to redefine and revitalize its development discourse for those countries and to consider the inequality case in Asia, Latin America and Africa countries rather than the growth (Table 4). 
Table 4. International Development Association Commitments to Countries Classified by Per Capita GNPa

\begin{tabular}{|l|c|c|c|c|c|}
\hline $\begin{array}{l}\text { Classification of } \\
\text { recipients }\end{array}$ & $\begin{array}{c}\text { Number of } \\
\text { countries }\end{array}$ & $\begin{array}{c}\text { Millions of U.S. } \\
\text { dollars } \\
(1961-1968)\end{array}$ & Percent & $\begin{array}{c}\text { Millions of U.S. } \\
\text { dollars } \\
(1969-1973)\end{array}$ & Percent \\
\hline Poorest (up to \$120) & 32 & 181 & 79 & 564 & 76 \\
\hline Indian subcontinent & 2 & 157 & 69 & 356 & 48 \\
\hline Indonesia & 1 & - & - & 90 & 12 \\
\hline Other & 29 & 24 & 10 & 118 & 16 \\
\hline $\begin{array}{l}\text { Intermediate }(\$ 121- \\
250)\end{array}$ & 29 & 21 & 9 & 109 & 15 \\
\hline Above \$250 & 4 & 27 & 12 & 59 & 8 \\
\hline
\end{tabular}

Source: Kapur et al., 1997, p.193.

aPer capita GNP figures are from 1972 World Bank Atlas.

bOther countries include Afghanistan, Burma, Burundi, Cameroon, Central African Republic, Chad, Congo, Dahomey, Ethiopia, Gambia, Haiti, Kenya, Laos, Malagasy Republic, Malawi, Mali, Nepal, Niger, Nigeria, Rwanda, Somalia, Sudan, Tanzania, Thailand, Togo, Uganda, Upper, Upper Volta, and Vietnam.

On the other hand in those years, there was loss of confidence to the term of national economic growth, which was seen as the main engine of the economic development, because it was widening unfair income distributions and inequalities in the most of the Third World countries. Furthermore, unfair income distributions and inequalities were rising due to the absence of the development approach and discourse, which had more general perspective and considering social dimensions of the development process. Albert Hirschman's statement about growth-oriented development and its deleterious side effects proved that:

"The series of political disasters that struck a number of the Third World countries from the 1960 's on were clearly somehow connected with the stresses and strains accompanying development and 'modernisation.' These development disasters, ranging from civil wars to the establishment of murderous authoritarian regimes, could not but give pause to group of social scientists." (Kapur et al., 1997: 231).

Moreover, there were some accurate views about the ending of the trickle down effect. In that context, Mason and Asher (1973) emphasized the necessity for defining new development discourse of the World Bank. Trickle down effect did not valid for all the Third World countries. Besides, they suggested that a broad measure of consensus existed about giving more attention to social and civic dimensions of the development process including employment creation, income distribution, participation, social justice (Kapur et al. , 1997: 221).

McNamara, the president of the Bank between 1968 and 1981, stated that the Bank started to give more importance to the poverty and distribution problems of the world rather than the growth. ${ }^{2}$ This fact was a kind of prove of the Bank's gradual shift from pure growth base development discourse to the poverty alleviation discourse. McNamara suggested the economic and social policies should permit more equitable distribution. In that context, he outlined a comprehensive program in Nairobi of developing strategies for attacking poverty (Finnemore, 1997: 212).

The Bank was anymore planning to carry out large rural development programmes focused on small farmers, as a vehicle for direct poverty alleviation (Kapur et al., 1997: 223). However, it began to define its development discourse not only on the axis of the economic growth, but giving importance to other factors as well. Economic development began to be evaluated as multidimensional process. Because there was still malnutrition, unemployment, illiteracy, the gap between rich and poor countries in the world despite high annual growth rates (United Nations, 1973). In this sense, the Bank started to adopt a new development discourse considering such kinds of facts.

Under the leadership of McNamara, the Bank made important contributions and supports to the Green Revolution. Green Revolution has sharply increased concentration of land ownership, massive 
dispossession of small-holders, proliferation of landless workers and increase in the domination of the multinational concerns over production and distribution of agricultural products and inputs (Feder, 1976: 532). That case reflected itself on the development and lending policies of the World Bank. The Bank began adopting the development discourse that provided subsistence agrarian economies especially. It started to give importance land and tenancy reforms and thus increased the productivity of small farmers. Beside, the Bank started to express social dimensions of the development process in order to prevent the deterioration of the poorest countries. In that context, it focused on health, nutrition, education and lending policies especially in the low income countries (Table 5).

Table 5. International Bank for Reconstruction and Development (IBRD) and IDA Lending during the McNamara Period, Fiscal 1969-1982

\begin{tabular}{|c|c|c|c|}
\hline \multirow[t]{2}{*}{ Borrowers $^{b}$} & \multirow{2}{*}{\multicolumn{3}{|c|}{$\begin{array}{c}\text { 1974-1982 Total } \\
\text { Millions of the U.S. Dollars }\end{array}$}} \\
\hline & & & \\
\hline Total & 11,215 & 79,207 & 90,421 \\
\hline High income & 811 & 770 & 1,581 \\
\hline Middle and low income & 10,401 & 78,437 & 88,840 \\
\hline Middle income & 6,499 & 48,248 & 54,747 \\
\hline Low income & 3,905 & 30,188 & 34,093 \\
\hline Middle and low income by sector & 10,404 & 78,437 & 88,840 \\
\hline Transport, power, telecommunications & 4,922 & 27,153 & 32,075 \\
\hline Agriculture, social $^{\mathrm{c}}$ & 3,267 & 31,694 & 34,961 \\
\hline Agriculture & 2,101 & 22,623 & 24,724 \\
\hline Education & 531 & 3,380 & 3,911 \\
\hline Population, health and nutrition & 71 & 489 & 559 \\
\hline Urban development & 25 & 1,374 & 1,399 \\
\hline Water supply and sewerage & 540 & 3,828 & 4,367 \\
\hline \multicolumn{4}{|c|}{$\begin{array}{l}\text { Source: World Bank, Financial Database Information and Kapur et al., 1973:234. } \\
\text { aMcNamara period includes commitments, from July 1, } 1969 \text { through June 30, 1982, based on the assumption that loan } \\
\text { commitments made during } 1982 \text { largely reflected lending decisions and preparations carried out under McNamara. } \\
\text { bHigh income borrowers: Bahamas, Cyprus, Finland, Greece, Iceland, Ireland, Israel, New Zealand, Singapore, Spain, and } \\
\text { Taiwan. Middle income borrowers: Algeria, Argentina, Barbados, Bolivia, Bosnia-Herzegovina, Botswana, Brazil, Cameroon, } \\
\text { Chile, Colombia, Congo, Costa Rica, Croatia, Djibouti, Dominica, Dominican Republic, Ecuador, El Salvador, Fiji, Gabon, } \\
\text { Guatemela, Indonesia, Iran, Iraq, Jamaica, Jordan, Korea, Lebanon, Macedonia, Malaysia, Maldives, Mauritius, Mexico, } \\
\text { Morocco, Oman, Panama, Papua, New Guinea, Paraguay, Peru, Philippiness, Portugal, Romania, Senegal, Slovenia, Solomon } \\
\text { Islands, Swaziland, Syria, Thailand, Trinidad and Tobago, Tunisia, Turkey, Uruguay, Venezuela, Western Samoa, and } \\
\text { Yugoslavia. Low-income borrowers: Afghanistan, Bangladesh, Benin, Burkina Faso, Burundi, Central African Republic, Chad, } \\
\text { China, Comoros, Cote d'Ivoire, Egypt, Equatorial Guinea, Ethiopia, Gambia, Ghana, Guinea, Guinea-Bissau, Guyana, Haiti, } \\
\text { Honduras, India, Kenya, Lao, Lesotho, Liberia, Madagascar, Malawi, Mali, Mauritania, Myanmar, Nepal, Nicaragua, Niger, } \\
\text { Nigeria, Pakistan, Rwanda, Sierra Leone, Somalia, Sri Lanka, Sudan, Tanzania, Togo, Uganda, Vietnam, Yemen, Zaire, Zambia, } \\
\text { and Zimbabwe. }\end{array}$} \\
\hline
\end{tabular}

The views of Hollis B. Chenery, prominent economist and Vice President of the World Bank between 1972 and 1982, were effective on the development discourse of the Bank in those years. ${ }^{3}$ Chenery's (1974) theory stated that in the early stages of a country's economic growth, the poorest segment of society deteriorated mostly. He emphasized that situation as below connotation:

"It is now clear that more than a decade of rapid growth in under- developed countries has been of little or no benefit to perhaps a third of the population."

Moreover, the opinions about the inadequacy of the economic growth for realization of the economic development gradually strengthened. Some views and studies developed about the term of development. Those views advocated that development should be handled with terms like employment, redistributions of growth and welfare. Addition, they criticised the development policies based only on the economic-growth (Seers, 1969; Haberler, 1970; Viner, 1970; Chenery 1974; Streeten, 1981) The World Bank considered these 
views and criticisms while it was determining development discourse and policies. The Bank brought about the basic needs approach ${ }^{4}$ through McNamara. Basic needs approach influenced the Bank's perspective on development and redefining as a real development agency (Akyüz, 2015:480). This approach was also adopted by the International Labour Organization (ILO). It was stated that the economic growth was not enough for the elimination of poverty and inequality problems of the world (ILO, 1976: 15-16). Addition, development was not only a financial issue, but also it had some social dimensions. Education, health, employment, environment, clean water etc., all those were considered substantial elements of development. So in this regard, the Bank began to give more importance to the social projects, lending and expenditures.

Therefore, the World Bank underwent a radical transformation in terms of development discourse and missions after the 1960s and until the end of the 1970s. The Bank initiated more projects and lent more fund to lower-income countries. Lending and borrowing volumes, number of projects and project objectives of the Bank expanded dramatically comparing number of personnel.

As a matter of fact, The Bank's development discourse continued to stick on Keynesian axis and theories, but it was not only the growth-centered no longer. Development discourse of the Bank gave attention the concepts such as poverty, inequality, situation of the Third World countries and also the social aspects of the development process.

\section{Fall of Keynesianism and Seeking for New Policies}

Nearly 30 years after the Second World War, many countries implementing Keynesian economic policies reflected the embeded liberal economic policies at the same time. Addition, the development economics discipline emerged after Second World War in order to find solutions for the reconstruction of the world. The emergence of the development economics brought modernization theories to the stage which substantially affected and dominated on the development discourse of the World Bank for few decades.

However, Keynesian economic policies and theories began to lose its effects. The first cracklings of the Keynesian economic system started to show itself with the series of currency crises in the late 1960s. The Vietnam War especially brought the huge financial burden on the U.S. economy. Foreign military spending accelerated the flow out of the U.S. dollar and caused the U.S. budget deficit, inflation and also growing balance deficits of payments. In order to overcome this case, the U.S. restrain foreign investments and headed through euro-dollar instead of dollar. Thus the U.S. gradually lost the control of capital movements. So that, it was not possible to maintain the fixed exchange rate system. Consequently, Bretton Woods system collapsed on 15 August 1971 by the announcement closing of the gold window of Richard Nixon, the president of the U.S. Other thing that led to the collapse of the Bretton Woods system were contradictions inherent in the system. On the one hand, dollar and its value in Bretton Woods system stayed fixed as a means of paymentas previously mentioned. Addition, its national currency and value must be variable as a competitive tool. However, different economies within the capitalist system have developed in different ways and speeds as a result of uneven development law. The US exports were higher than imports for a long period following the Second World War, because there were increased demand for its goods. But, developing European countries and Japan, in terms of the production of capital and consumer goods, were becoming serious competitors of the U.S. as of the middle of the 1960s. As a result of these progresses, the U.S. trade balance started to give deficit and balance of payments deteoriated towards the end of the 1960s. These circumstances brought about the internationalization of capital and enhancement of its mobility; also the collapse of the Bretton Woods system.

Another factor caused the losing influence of the Keynesian economic policies was the oil crisis began in 1973 with the rapid rise of the oil prices. Many oil importer countries particularly the least developed ones faced external payment difficulties and macroeconomic instabilities by the effects of high oil prices (Table 6). Parallel to the oil crises, current account deficits increased especially for developing countries. Addition, production volumes of many sectors went down, on the other hand, price and unemployment levels increased. All those cases caused a new fact observed in many economies simultaneously called stagflation ${ }^{5}$. 
Herewith, a new economic theory quest has arisen especially to clean away the stagflation from many economies because Keynesian demand-side policies have failed to find solutions to that problem.

Table 6. Responses of Developed and Developing Countries to the Oil Shocks of the 1970s

\begin{tabular}{|c|c|c|c|c|c|c|c|c|c|c|}
\hline & \multicolumn{10}{|c|}{ Years } \\
\hline & 1973 & 1974 & 1975 & 1976 & 1977 & 1978 & 1979 & 1980 & 1981 & 1982 \\
\hline Oil prices $^{a}$ & 2.70 & 9.76 & 10.72 & 11.51 & 12.40 & 12.70 & 16.97 & 28.67 & 32.57 & 33.49 \\
\hline & \multicolumn{10}{|c|}{ Industrial countries } \\
\hline Growth rate $^{c}$ & 5.59 & 0.02 & -1.07 & 4.40 & 3.42 & 5.52 & 2.51 & 0.97 & 1.49 & -1.19 \\
\hline \multirow[t]{2}{*}{ Current account surplus ${ }^{b}$} & 20 & -11 & 20 & 1 & -2 & 33 & -6 & -40 & 1 & -1 \\
\hline & \multicolumn{10}{|c|}{ Oil-exporting developing countries } \\
\hline Growth rate & 6.39 & 5.34 & -1.29 & 5.93 & 1.50 & -3.56 & 3.96 & -4.66 & -4.59 & 1.63 \\
\hline \multirow[t]{2}{*}{ Current account surplus ${ }^{b}$} & 7 & 68 & 35 & 40 & 30 & 2 & 69 & 114 & 65 & -2 \\
\hline & \multicolumn{10}{|c|}{ Other developing countries } \\
\hline Growth rate $^{c}$ & 4.34 & 3.75 & 2.85 & 3.22 & 4.02 & 3.09 & 2.16 & 3.31 & 1.54 & -2.11 \\
\hline Current account surplus ${ }^{b}$ & -11 & -37 & -46 & -31 & -29 & -41 & -61 & -89 & -108 & -87 \\
\hline
\end{tabular}

Sources: IMF (1981, 1983, 1985); Summers and Heston (1988), transmitted by Gilbert and Vines, 2006:162.

aUS \$/ barrel, for Saudi Arabian crude at Ras Tanura.

bUS \$ billion, in IMF (1983) definitions.

cPer cent. Weighted average growth rate of real GDP per capita, with weights given by real GDP'S as a share of group's real GDP.

Friedman brought about the new explanations and solutions to the stagflation problem. The rise of the petrol prices was not the single problem caused stagflation, but the economic policies of the Keynesian welfare state also leaded to stagflation (Friedman, 1953, 1962 and 1976). It was claimed that the high aggregate demand, employment policies, high tax rates and social welfare expenditures of the Keynesian policies only created negativity (Bayraktar, 2012: 260). Lucas (1972) and some other economists explained this situation with some empirical evidences and discussions after Friedman criticized these policies.

Furthermore, Friedman created the term of monetarism emphasizing the desirability of predetermined rules to conduct monetary affairs, to provide the stability of the economy and the efficiency of the market mechanisms and also to break up the unfavorable effects of destabilizing fiscal policy (Parasız, 1991: 46).

The role of Friedman cannot be ignored on the failure of the Keynesianism, who exhibited the invalidity of it especially after 1970s. Lapavitsas (2005: 34)'s statements verifies that claim:

"In mainstream economic theory, the charge against Keynesianism was led by Milton Friedman's monetarism, which is a resurrected version of the Quantity Theory of Money. Inflation, the key economic problem of the 1970's, was treated by Friedman as purely monetary phenomenon resulting from too much money chasing after too few goods. For Friedman, it is not possible for governments to choose among combinations of inflation and unemployment. He argued that capitalist economies have a 'natural rate' of unemployment, and any attempt to bring the actual rate of unemployment, below the 'natural' would merely lead to inflation."

Therefore, under effects of all those developments, the World Bank underwent a radical transformation in respect to development discourse between the mid of 1960s and the mid 1970s. Roughly in 1970s, the Bank's main development discourse shaped on the alleviation of poverty axis, as defined by McNamara at the Bank's Annual General Meeting at Nairobi in September 1973. But approximately month after, Organization of the Petrolium Exporting Countries (OPEC) announced 70 percent increase in oil prices and after that second devaluation of dollar in February 1973 was realized. The first devaluation had resulted in the collapse of the Bretton Woods fixed exchange rate regime. Furthermore, in February 1974 termination of capital controls in the U.S. was realized and this radical transformation caused financial global imbalances in many important countries including Japan and Germany which they faced large current account deficits 
and closed their capital markets to the Bank while oil producer OPEC countries were significantly escalating their current account surpluses. In that context, this sudden oil shocks and stagflation fact obliged the Bank to adopt new and directive discourse. The Bank started to give more attention to policies and lending towards the oil importer countries and also tried to cultivate a new market consisted of OPEC countries.

Then, the first issue of the World Bank was to examine how developing countries were financially challenged by the oil crisis and also to find solutions for that situation. The Bank's main concern became struggling with inflation and finding proper solutions to the problem of developing countries dependent on the importation of oil for their energy needs that financially challenged by the increasing costs. Grant (1974: 1-2) pointed out the main concerns of the Bank for the developing world in that period:

"The admittedly limited goal of increasing growth rates was jeopardized in a majority of developing countries... by the jolt of sudden, massive price increases in their essential imports, primarily oil, food and fertilizers, and by the impending global economic slowdown. The development prospects of some of the most populous poor countries... were thus even more gravely endangered for the balance of the decade. And some of the higher-income developing countries... now faced serious short-term disruption."

After the oil shocks, the Bank's borrowings from OPEC countries dramatically rised. ${ }^{6}$ The total volume of borrowings and lendings of the Bank also rised significantly (Table 7 and 8 ).

Table 7. IBRD Planned Borrowings and Lending, Fiscal between 1969 and $1978^{\mathrm{a}}$

\begin{tabular}{lcccc}
\hline Borrowing/Lending & $\begin{array}{c}\text { Actual 1969- } \\
1973\end{array}$ & $\begin{array}{c}\text { Projected } \\
\text { end-1971 }\end{array}$ & $\begin{array}{c}\text { Projected end- } \\
1974\end{array}$ & $\begin{array}{c}\text { Actual 1974- } \\
1978\end{array}$ \\
\hline & \multicolumn{4}{c}{ Billions of U.S. Dollars } \\
Commitments & 8.9 & 14.0 & 22.1 & 22.4 \\
Gross Disbursements & 4.7 & 9.8 & 12.5 & 11.4 \\
Net Disbursements & 2.9 & 6.7 & 9.2 & 8.4 \\
Borrowings & 6.8 & 11.3 & 13.9 & 17.5 \\
\hline
\end{tabular}

Source: Kapur et al. , 1997: 981.

aLending figures do not include loans to the IFC or to developed countries.

Table 8. Net Resource Receipts of Developing Countries between 1970 and 1979

\begin{tabular}{lcccc}
\hline & \multicolumn{3}{c}{ Years } \\
Source & $1970-1974$ & \multicolumn{3}{c}{$1975-1979$} \\
\hline & Billions of US Dollars & Percent & Billions of US Dollars & Percent \\
World Bank & 5.8 & 4.6 & 16.6 & 5.0 \\
IBRD & 3.4 & 2.7 & 10.7 & 3.2 \\
Other Multilateral & 8.5 & 6.7 & 24.0 & 7.2 \\
Bilateral & 40.9 & 32.3 & 84.9 & 25.4 \\
Private & 32.8 & 25.9 & 92.6 & 27.7 \\
Export Credits & 13.9 & 11.0 & 48.7 & 14.6 \\
FDI & 17.1 & 13.5 & 52.5 & 15.7 \\
Other & 7.8 & 6.2 & 15.1 & 4.5 \\
\hline Total & 126.8 & 100.0 & 334.4 & 100.0 \\
\hline
\end{tabular}

Source: OECD, (1980).

Meantime, none of countries in the world was no longer unrivaled in global markets in the terms of capital and labor. The World Bank had invested so much in fixed capital, capacity building and infrastructure by the late 1960s, the post-war expansion period, in many conutries especially in the U.S., the Western Europe and Japan; nonetheless their profit rates had begun to decrease. On the other hand, particularly after the collapse of the Bretton Woods fixed exchange rate system, the control on the capital inflows and outflows were removed by many countries and that case brought the phenomenon of financialization. Therefore, the Keynesian-type economic policies were no longer attractive to capitalist profitability, and also for the 
definition of the development strategies. Toporowski (2010: 18) stated about the invalidness of the Keynesian economic policies as below:

"It should be emphasized that Keynesian stabilization policies were not abandoned for purely ideological reasons; i.e., because, as many critics of neo-liberalism argue, a laissez-faire animus spread from Chicago, infecting politicians of all parties and persuading them of the benefits of free markets. Keynesian systems of financial regulation (capital controls and managed exchange rates) could not withstand the growing pools of unregulated international credit, the Euromarkets, which came to dominate international finance."

Eventually it is possible to state that, the transformation of the world made necessary shiftings of the economic theory. New economic and development theory called neoliberalism emerged especially at the late 1970s. In that context, Thacther and Reagan, Prime Minister of England and President of the U.S., respectively, restructured their economic projects towards trials and applications of the neoliberal economic theories. Therefore, many world economies entered into neoliberal turn ${ }^{7}$ from the Keynesianism.

\section{The 2008 Crisis and the Rebirth of Keynesianism}

The global economic crisis of 2008/2009 started in the US real estate market in 2007; the economic crisis that has become a global crisis with the expansion of demand caused by the decline in the prices of the assets, the contraction of the liquidity and the uncertainty in the country through the international trade channels (Frenkel \& Rapetti, 2009: 2). Many of the Keynesian prescriptions proposed for exit from this global economic crisis have begun to be implemented in various forms in many countries, particularly in the US.

This is what we have seen in the history of economics, we have seen this film in 1929. In the crisis of 1929 , the loan stock reached large volumes, high growth rates were achieved in the US industrial and agricultural sectors, and the US stock markets were waned. However, with the economic movement of the Soviet Union in the aftermath of the October Revolution of 1917, significant growth rates were observed in the agricultural sector and this increased the grain exports in particular. However, the increase in global grain prices after this increase combined with the puffiness of the economic structuring of the US gave rise to the 1929 crisis.

The causes of these two crises show great similarities: bulge in the financial markets, low tendency to save and supply surplus in the commodity market. The crisis of 1929 not only showed the results of the lack of effective demand for economists but also French economists. Say's famous claim ("every supply creates its own demand") was invalidated. More precisely, it showed that supply-side economics collapsed in the crisis. The crisis of 1929, J.M. The idea of Keynes' demand for state intervention in the economy was started to be solved in 1932 with the introduction of it in the US.

The 2008 crisis has common characteristcs with the 1929 crisis as it can be understood. In overcoming the crisis, the FED did not repeat its error in 1929 and gave it the liquidity of the market. However, the uncertainty environment prevents the liquidity remaining in the financial markets. This may lead to a deepening of the crisis and the collapse of firms in the real sector.

The first reaction to the crisis was monetary policy but when it failed, the fiscal policy and rescue packages were brought up in the Keynesian context. The recovery of large-scale banks, insurance and financial institutions and industrial companies, particularly in the United States and the UK, required the use of huge amounts of public resources. The treasury and central banks of developed countries injected about $\$ 21$ trillion into the global financial system to save the financial system. This figure equals one and a half times of the US GDP (McNally, 2013: 54). This policy helped to soften the panic environment created by the crisis to a certain extent and in particular to save the financial sector. Remarks such as the downsizing of the state frequently mentioned by neoliberal discourse and the reduction of public expenditure suggestion were forgotten at the time of the crisis and the bank and insurance company were rescued by the state.

After the initial response of the rescue packages, countries implemented stimulus packages to bring their economies out of contraction and stagnation. While the stimulus packages show some differences with 
respect to the countries, they include a large increase in public spending and tax reduction. Increasing public spending to overcome the congestion, the reduction of taxes and the increase of transfer expenditures and public policies to increase demand are important in terms of showing the adoption of the Keynesian approach as the liberator of neoliberal capitalism (Kotz, 2009).

This crisis, as mentioned in the previous chapters, demolished the supply-side economic policies, which became popular again after 1980, as well as the institutional structure created by these policies (supreme boards, such as the release of capital movements). The FED's intervention in the financial markets seems to bring a more efficient state model to the economy. Especially the industrialized countries have accepted this.

Keynes argued that markets could not be left on their own, and that the state should play a regulatory role in the economy. This proposal and the model behind it has been the model of the exit from the great crisis. In time, the state has again turned to retreat. The global system change experienced in the 1990s led to a similar crisis in the mid-2000s. Now again, Keynesian policies are reverted to the state, and it is still turning to expropriations and funds (Eğilmez, 2008). As you can see, crises are the normal mechanisms of operation in which capitalism sees extreme conditions such as speculation and investment balloons. In times of crisis, government policies should be seen as tools that make the process of reorganization much softer until the next explosion of capitalism.

The 2008 crisis has deeply influenced the work of international organizations that have influenced development policies in the world such as the World Bank and the IMF and has led them to cooperate at this point. During the crisis, the IMF has taken the responsibility of supporting the member states. It had previously proposed policy solutions based on his experience of transition economies to developed and advanced countries, felt the need to take more responsibility by modernizing credit mechanisms and taking into account the needs of member states (Kato, 2009: 2).

After the crisis, the IMF has made some changes in itself. These include: (1) Expansion of the global financial security network, (2) Increasing the flexibility in IMF loans, (3) Strengthening the surveillance, (4) Becoming a more utilizable organization (Kato, 2009: 2).

On the other hand, the World Bank's action to respond to the crisis, prepared in late 2008 and early 2009, concentrated on the following key objectives: (i) preserving the most defenceless towards the fallout of the crisis; (ii) sustaining long- term infrastructure programs; and (iii) maintaning the potential for private sector- led growth and employment creation, especially by means of small and medium enterprises and microfinance (World Bank, 2009: 7). In order to realize them, it started to drop gradually the pure neoliberal development discourses and have focused on the development through the state intervention in order to maintain the system, which belongs substantially to the Keynesian policies.

Eventually it is possible to state that, until the 1970s, the basic contradictions and crises of capitalist production and distribution relations in advanced capitalist countries such as the USA, Europe and Japan, the so-called Keynesian big-consensus, high growth rates, widespread technological progress, improvement in health and social security, increase in purchasing power and declining tendency in unemployment the Keynesian currency and fiscal policies that have enabled them to gain power; it is trying to overcome the global crisis of 2008 in a similar way but this time with new governmental interventions and New-Keynesian reconciliation policies.

\section{Conclusion}

The Keynesianism constituted the dominant theory for understanding the determination of the World Bank's development policies roughly around 25 years between 1945 and 1970s. This period was represented the era of which the main wisdom based on the Great Depression and post-war economic experiences in the countries of North and West.

However, towards the end of the 1960s, Keynesian economic policies and developmental state models started to give bad signals and falling into disarray. As a matter of fact, that system had delivered 
high rates of growth, especially to the advanced capitalist countries and created some spillover benefits; most definitely to Japan and Western Europe; but also unequally across South America and to some different countries of South East Asia during the golden age of capitalism in the 1950s and early 1960s. But it was unsustainable anymore; that fact was broadly understood. Furthermore, a dramatic recession brought by the petrol crises prompted many views about the ineffectiveness of Keynesian economic policies for explanation and solution of the development problems.

All those progresses required the gradual appeal to the new economic and development theory throughout the world by means of the World Bank. Neoliberalism emerged as new economic and development theory for World Bank after Keynesianism. That policy evolution and transformation of the Bank will constitute the subject of the another article. However with the 2008 crisis it has lost its impact and this case resulted with the rebirth of the Keynesian economics. As a matter of fact, the 2008 global economic crisis for neoliberal understanding has been a breaking point for the dominance of neoliberal ideas in the academic world. While the most severe economic crisis experienced by humanity after the Great Depression highlighted the need for reform in the global economic system based on capitalism, the search for new paradigm in the economic circles came to the agenda. The crisis of 2008 has led states to bring together states for the reconstruction of the global financial system, to refute the neoliberal principles and the selfregulating mechanisms of markets, to reorganize the financial markets and to more rigorously control. In this way, the paradigm shift, which again highlights the role of state power and regulatory authority on global financial markets and firms, has gained momentum.

Within this framework, some reforms in the international financial and economic system during the global economic crisis of 2008/2009 accepted by many economists and politicians. However, the content and scope of the reforms and there is no consensus on its philosophy. At this point, global Keynesian proposals that advocate the realization of these reforms in accordance with the Keynesian analytical system are becoming increasingly important. With a new and radical international financial structure to be carried out in line with global Keynesian proposals, the governments of the country can regain autonomy in fiscal and monetary policies and capital controls to check net international flows. In this context, surplus excess surpluses must be distributed through goods purchases, foreign direct investments and official development assistance.

Eventually it is possible to state that the crisis evolved into the economic structure dominated by the multinational corporations in which neoliberal economic policies were followed, and in this sense changed the prescriptions of the economy offered by various international institutions to the World, mainly the World Bank. In this context, various discourses such as social market economy, capitalism, global Keynesianism, which are regulated by the state, are proposed by these organizations. It can be said that an economic structure and a system where the weight of the state increased. Suggestions to reduce the state in the past and to deactivate the state are no longer defended. A renewal, restoration requirement is generally accepted in order to sustain capitalism.

\section{End Notes}

1. However economic development for developing and less-developed countries was largely attributed to the adoption of the economic, political, social and cultural structures of the Western societies by modernization theory. That theory also defined development apart from the historical processes of countries and regarded development as universal and linear process. However, the modenization theory would gradually lose its impact on development discourse after the middle of 1960's.

2. Mc Namara often emphasized that 'growth, by itself, is not enough.' The social aspects of development were also important. And poverty alleviation must be the main focus and discourse of the World Bank (See Kapur et al., 1997, p.360).

3. Hollis Chenery created a "broader view" of economic growth (away from the neoclassical model) which involved structural changes in the reallocation of resources to realize economic growth in developing countries (See, Chenery 1971 and Chenery 1974). 
4. Basic needs approach is one of the crucial approach while measuring the absolute poverty in countries. Traditional list of the basic needs includes food, shelter and clothing and beside them sanitation, education and healthcare. This approach was largely introduced by the International Labour Organization's World Employment Conference in 1976. Then, it was developed by Paul Streeten who was a senior adviser to the World Bank, helping to define development policies on basic needs.

5. In economics, stagflation is a situation in which inflation rate is high, economic growth rate slow, and also unemployment levels are high simultaneously. It largely occurred after the first petrol crisis in 1973 and the second one in 1979. Keynesian policies failed to explain that problem; because Keynes advocates that the impossibility of realization of unemployment and inflation simultaneously. He advocates that there is always trade-off between economies as Philips Curve represented. But petrol crisis showed the contrast situation of those advocacies. Thus, stagflation became a fact showing gradually the invalidity of the Keynesian economic policies.

6. Within the eighteen months following the oil shock, nearly 80 percent (\$2.2 billions) of the Bank's net borrowings of $\$ 2.8$ billions was raised from OPEC countries such as Iran, Nigeria, Saudi Arabia and Venezuela. For more details see Kapur et al., 1997: p. 973.

7. Neoliberalism refers to the dominant paradigm substituting the modernist concepts of embedded liberalism, objectified by the 1979 election of Margaret Thatcher in Britain and 1980 election of Ronald Reagan in the United States. Deregulation, liberalisation of markets, and privatisation extended not only to industrial and financial policy but also into fields of social policy for example housing, health and education. World Bank's neoliberalism age can be defined mostly by the structural adjustment programs and Washington Consensus. Even though, towards the end of the 1990's it has melted its picture and enlarged its agenda through the broader focus on social spending and poverty reduction, The Bank achieved the sharpest policy change towards Keynesian economics with the 2008-2009 crisis.

\section{Acknowledgement}

I would like to thank to my thesis supervisor Assoc. Prof., PhD., Muammer Kaymak for his contributions which I produced from my master thesis.

\section{References}

Akyüz, E. (2015). The World Bank and the evolution of the development thinking. The Journal of Academic Social Science, 3(21), 475-484.

Balaam, D. N., \& Dillman, B. (2015). Uluslararası ekonomi politiğe giriş. Translated by: Nasuh Uslu, Ankara: Liberte.

Başkaya, F. (2005). Kalkınma iktisadının yükselişi ve düşüşü. Ankara: İmge.

Bayraktar, C. (2012). Keynes ve refah devleti. Celal Bayar Üniversitesi Social Sciences Journal, 10(2), 247-260.

Chenery, H. (1971). Growth and structural change. Finance and Development, 8(3), 16-27.

Chenery, H. (1974). Redistribution with growth. London: Oxford University Press.

Eğilmez, M. (2008). Küresel krizin nedenleri. Radical Newspaper, 23.09.2008.

Eichengreen, B. (2010). Lessons from the Marshall Plan. World Bank, World Development Report 2011. Background Case Note.

Feder, E. (1976). Mc. Namara's little green revolution: World Bank scheme for self- Liquidation of third world peasantry. Economic and Political Weekly, 11(14), 532-541.

Finnemore, M. (1997). Redifining development at the World Bank, In: Frederick Cooper, Randall Packard (Eds.), International development and the social sciences: Essays on the history and politics of knowledge, (pp. 203-227), US: University of California Press.

Frenkel, R., \& Rapetti, M. (2009). Some reflections on the current global crisis from a developing countries perspective. Friedrich Ebert Stiftung Briefing Paper, No. 6, May.

Friedman, M. (1953). The case for flexible exchange rates. In Milton Friedman (Ed.), Essays in Positive Economics, (pp. 157-203), Chicago: University of Chicago Press.

Friedman, M. (1962). Capitalism and freedom. Chicago: University of Chicago Press. 
Friedman, M. (1976). Price theory: A provisional text. New York: Aldine de Gruyter.

Gilbert, C. L., \& Vines, D. (2006). The World Bank: An overview of some major issues. In Christopher L Gilbert, David Vines (Eds.), The World Bank: Structure and Policies, (pp. 10-36), UK: Cambridge University Press.

Grant, J. P. (1974). Energy shock and the development prospect The U.S. and the development world: Agenda for action. Newyork: Praeger Publishers.

Gwin, C. (1997). US relations with the World Bank, 1945-1992. In Devesh Kapur, John Lewis and Richard Webb (Eds.), The World Bank: It's first half-century, in perspectives, (pp. 195-274), Washington DC: Brookings Institution.

Haberler, G. (1970). Dynamic benefits of trade. In G. M. Meier (Ed.), Leading Issues in economic development, (pp. $492-$ 497), Newyork: Oxford University Press

Harvey, D. (2007). Neoliberalism as creative destruction, The Annals of the American Academy of Political and Social Science, 610(1), 21-44.

Hogan, M. J. (1989). The Marshall Plan: America, Britain and the reconstruction of Western Europe, 1947-1952. UK: Cambridge University Press.

ILO (1976). Employment, growth and basic needs: A One world problem. The International Basic Needs Strategy Against Chronic Poverty and the Decisions of the World Employment Conference, Newyork, Praeger, 11, ISBN:0- 03- 02021601- 0.

Kapur, D., Jewis, J. P., \& Webb, R. (1997). The World Bank, It's first half century. Washington DC: Brookings Institution Press.

Kato, T. (2009). The IMF's response to the global crisis. http://www.imf.org/external/np/speeches/2009/062509.htm. Access Date: 06/12/2018.

Kaynak, M. (2009). Kalkınma iktisadı. Ankara: Gazi.

Kotz, D. (2009). The financal and economic crisis of 2008: A systemic crisis of neoliberal capitalism. Review of Radical Political Economics, 41(3), 305-317.

Kesselman, M. (1973). Order or movement? The literature of political development as ideology. World Politics, 26(1), $139-154$

Lapavitsas, C. (2005). Neoliberalism a critical reader. In A. Saad-Filho \& D. Johnston (Eds.), Mainstream economics in the neoliberal Era, (pp. 30-40), London: Pluto Press.

Lucas, R. E. (1972). Expectations and neutrality of money. Journal of Economic Theory, 4, 103-124.

Mason, E. S., \& Asher, R. (1973). The World Bank since Bretton Woods. US: Brookings Institutions Press.

Meier, G. M., \& Seers, D. (1984). Pioneers in development. London: Oxford University Press.

OECD (1980). Economic Outlook No 27 - June 1980 - Annual Projections for OECD Countries. (Access Link: https://stats.oecd.org/Index.aspx?DataSetCode=EO27_VINTAGE - Access Date: 16/ 06/ 2017).

Parasız, i. (1991). Monetarizm ve friedmancı düşüncenin temelleri. Tekstil ve Mühendis, 5(25), 46-50.

Prebisch, R. (1950). The Economic development of Latin America and its principal Problems. Newyork: United Nations.

Rabe, S. G. (1988). Eisenhower and Latin America: The foreign policy of anticommunism. US: Chapel Hill: University of North Carolina Press.

Rosenstein-Rodan, P. (1943). Problems of industrialization of Eastern and South Eastern Europe. Economic Journal, 53, 201-221.

Rosenstein-Rodan, P. (1961). International aid for underdeveloped countries. Review of Economics and Statistics, 43(2), 107-138

Ruggie, J. G. (1982). International regimes, transactions and change: Embedded liberalism in the postwar economic order. International Organization, 36(2), 379-415.

Seers, D. (1969). The meaning of development. International Development Review, 11(2), 2-6.

Streeten, P. (1981). First things first, meeting basic human needs in developing countries. Newyork: Oxford University Press.

Toporowski, J. (2010). Why the world economy needs a financial crash and other critical essays on finance and financial economics. London: Anthem Press.

Toussaint, E. (2008). The World Bank: A critical primer. Translated by E. Anne et al., London: Pluto Press.

United Nations. (1973). Implementation of the international development strategy. Newyork: United Nations. 
Viner, J. (1970). The concept of "disguised unemployment". In G. M. Meier (Ed.), Leading Issues in Economic Development. (pp. 151- 156), Newyork: Oxford University Press.

World Bank. (2009). The World Bank Group's response to the global crisis: Update on an ongoing IEG evaluation (English). IEG evaluation brief; no. 8. Washington, DC: World Bank.

Zabçı, F. (2009). Dünya Bankası yanılsamalar ve gerçekler. İstanbul: Yordam. 